\title{
Salmonella enterica Arthritis in a Patient with Rheumatoid Arthritis Receiving Anti-tumour Necrosis Factor Therapy \\ M Bubonja-Sonje ${ }^{1}$, D Rubinic ${ }^{2}, \mathrm{~F}_{\text {Anic }}{ }^{3}, \mathrm{~S} \mathrm{Novak}^{3}$, D Vuckovic ${ }^{4}, \mathrm{M} \mathrm{Abram}^{1}$
}

\begin{abstract}
Anti-tumour necrosis factor (TNF) monoclonal antibodies have become an invaluable treatment against chronic inflammatory diseases such as rheumatoid arthritis (RA). However, due to increased risk of opportunistic infections, patients receiving anti-TNF therapy should be closely monitored for serious infections. Here, we describe a case of acute Salmonella_enteritidis infection of a joint arthroplasty that previously was functioning well, in a patient receiving infliximab treatment for RA. After prolonged antimicrobial chemotherapy and interrupted infliximab treatment, reimplantation of a new prosthesis was successfully performed two years after Salmonella septic arthritis. Therefore, because of the possibility of extraintestinal salmonellosis, screening for fecal colonization could be advisable in patients undergoing anti-TNF treatment. Moreover, we emphasize the importance of appropriate counselling of these patients concerning food hygiene.
\end{abstract}

Keywords: Anti-TNF treatment, knee infection, Salmonella enteritidis

\section{Artritis por Salmonella enterica en un Paciente con Artritis Reumatoide que Recibe Terapia con Factor de Necrosis Antitumoral}

M Bubonja-Sonje ${ }^{1}$, D Rubinic ${ }^{2}$, F Anic ${ }^{3}$, S Novak ${ }^{3}$, D Vuckovic ${ }^{4}$, M Abram ${ }^{1}$

\begin{abstract}
RESUMEN
Los anticuerpos monoclonales del factor de necrosis antitumoral (FNT) se han convertido en un valioso tratamiento contra las enfermedades inflamatorias crónicas como la artritis reumatoide (AR). Sin embargo, debido al mayor riesgo de infecciones oportunistas, los pacientes que reciben terapia antiFNT se deben se monitoreados muy de cerca con respecto a la posibilidad de infecciones serias. Aqui describimos un caso de infección aguda por Salmonella enteritidis de una artroplastia de articulación que anteriormente funcionaba bien, en un paciente que recibia tratamiento con infliximab por $R A$. Después de prolongadas quimioterapias antimicrobianas y tratamiento interrumpido con infliximab, se realizó exitosamente la reimplantación de una nueva prótesis, dos años después de la artritis séptica por Salmonella. Por lo tanto, debido a la posibilidad de una salmonelosis extraintestinal, podría ser aconsejable el tamizaje de la colonización fecal en pacientes sometidos a tratamiento anti-FNT. Por otra parte, hacemos hincapié en la importancia de aconsejar apropiadamente a estos pacientes con respecto a la higiene de los alimentos.
\end{abstract}

Palabras claves: Tratamiento anti-FNT, infección de la rodilla, Salmonella enteritidis

West Indian Med J 2013; 62 (3): 270

From: ${ }^{1}$ Department of Clinical Microbiology, University Hospital Rijeka, Rijeka, Croatia, ${ }^{2}$ Lovran Clinic for Orthopaedic Surgery, Lovran, Croatia, ${ }^{3}$ Department of Internal Medicine, University Hospital Rijeka, Rijeka, Croatia and ${ }^{4}$ Department of Microbiology, Faculty of Medicine, University of Rijeka, Rijeka, Croatia.

Correspondence: Dr M Bubonja-Sonje, Department of Clinical Microbiology, University Hospital Rijeka, Kresimirova 42, 51000 Rijeka, Croatia Fax: +385-51-658-841, e-mail: marina.bubonja@medri.uniri.hr

\section{INTRODUCTION}

The increased risk of serious infections in patients with rheumatoid arthritis (RA) is attributable to the disease process itself, as well as to the immunosuppressive properties of its treatment. Anti-tumour necrosis factor (TNF) therapy, used for immunomodulation in RA, is mostly associated with reactivation of opportunistic infections primarily caused by 
intracellular bacteria such as Salmonella, Mycobacterium, and Listeria (1-4). The presence of a prosthetic implant may additionally change the likelihood of complications from an otherwise transient bacteraemia.

\section{CASE REPORT}

We describe a case of $S$ enterica serotype enteritidis infection of a right total knee arthroplasty in a 62-year old patient. She was diagnosed with RA in 1986, and subsequently received long-term immunosuppressive treatment with methotrexate (15 mg weekly) and corticosteroids (5 mg prednisone daily). Total knee arthroplasty (TKA) was performed on the right knee in 2005. Treatment with infliximab was introduced in 2007. However, in May 2008, the sixth day after a 14-day administration of infliximab, she presented to clinic with sudden knee pain and infectious clinical symptoms. She reported five days of chills followed by high grade fever, and an acutely painful, swollen knee with stiffness and effusion. There was no history of trauma. Physical examination revealed important signs of inflammation in her right knee (tenderness to palpation, swelling, increased warmth and limited range of motion). Laboratory analysis showed elevated C-reactive protein (CRP) $132 \mathrm{mg} / \mathrm{L}$, erythrocyte sedimentation rate $86 \mathrm{~mm} / \mathrm{h}$ (Westergren) and white blood cell $\left(\mathrm{WBC}\right.$ ) count $8.9 \times 10^{9} / \mathrm{L}$. Before antimicrobial therapy, joint aspiration was performed and synovial fluid, simultaneously with two samples for blood cultures, was sent to the microbiology laboratory. There were no crystals on microscopic examination and Gram stain of fluid was negative. Blood cultures were also negative, but synovial fluid grew pure culture of Salmonella enteritidis. Susceptibility testing showed sensitivity to most commonly used antimicrobials. The patient's past medical history included gastrointestinal salmonellosis approximately eight years before; she also had a history of recent travel to Turkey, a country with a high burden of salmonellosis. As the patient's condition did not improve significantly after five days of initial therapy, arthroscopic lavage and debridement were performed. Intravenous ceftriaxone was introduced and the patient got better. Infliximab treatment was stopped and therapy was not resumed. However, at the end of June 2008, after recurrence of the infection, open arthrotomy with irrigation and synovectomy with retention of prosthesis were done. Because of persistent knee pain and fistula formation, in April 2009, the joint had to be removed. While there were no further indications of infection, in February 2010 exchange arthroplasty was performed. The patient is now two years post second arthroplasty and continues to do well.

\section{DISCUSSION}

Prosthetic joint infection remains one of the most devastating complications after total joint arthroplasty, a common procedure in patients with RA. Although it is still controversial whether the use of TNF-alpha blocking agents per se increases the risk of infection or not (5-7), recently, a prospective observational study showed small but significant overall risk of serious infections (8).

The present case report provides supporting evidence that patients receiving anti-TNF treatment have an increased susceptibility to Salmonella infections, which may develop at unusual localizations. Salmonella osteomyelitis is an uncommon disease, usually associated with sickle cell anaemia (9), other haemoglobinopathies (10), as well as with other disease states. Septic arthritis is a rare consequence of Salmonella bacteraemia, noted in less than $1 \%$ of cases. A few cases of extraintestinal Salmonella infections affecting bones and joints in anti-TNF treated patients have been previously reported (11-12). Since the joint infection is a rheumatology emergency that requires early diagnosis, it is appropriate to consider the possibility of septic arthritis in RA patients with knee arthroplasty who have undergone biologic therapy. The usual pathogenesis of Salmonella septic arthritis is thought to be haematogenous rather than direct inoculation into the joint; Salmonella septic arthritis has not been considered an intraoperative contaminant during joint replacement. In addition, infections that occur later than three months after joint arthroplasty are usually haematogenously acquired.

Although the patient described in this report did not present with any gastrointestinal symptoms, nor had positive fecal cultures, she had a history of enteric salmonellosis and recent travel to a high-risk endemic country, so haematogenous seeding of the knee still seems likely. Surgery was required to eradicate the infection but, finally, the patient had a successful clinical outcome of septic revision TKA.

Anti-TNF agents are remarkably effective in the treatment of chronic inflammatory rheumatic diseases. While they may be associated with an increased risk of opportunistic infections, these risks are not excessively high. Still, not all of the association between anti-TNF therapy and joint infection may represent a direct causal pathway. The infection risk is no reason to withhold therapy with TNF- $\alpha$ inhibitors; indeed, removal of anti-TNF therapy could lead to a worse functional status and increased risk of infection through that mechanism.

The risks of serious infections in patients undergoing anti-TNF treatment is overcome by testing for and treating existing latent infections, and adopting appropriate precautions prior to and during treatment with biological agents to minimize risk.

Screening for Salmonella fecal colonization could be advisable in these patients, and the diagnostic algorithm has to be designed for early diagnosis and treatment of possible salmonellosis. In addition, we emphasize the importance of appropriate counselling of these patients concerning food hygiene. In conclusion, there is need to summarize current knowledge which could provide evidence-based recommendations to reduce the salmonellosis risk among candidates for anti-TNF therapy as it has been done recently for tuberculosis risk (13). 


\section{REFERENCES}

1. Rijkeboer A, Voskuyl A, Van Agtmael M. Fatal Salmonella enteritidis septicaemia in a rheumatoid arthritis patient treated with a TNF-alpha antagonist. Scand J Infect Dis 2007; 39: 80-3.

2. Bassetti M, Nicco E, Delfino E, Viscoli C. Disseminated Salmonella paratyphi infection in a rheumatoid arthritis patient treated with infliximab. Clin Microbiol Infect 2010; 16: 84-5.

3. Choi SW, Ahn JJ, Hwang YT, Koh SH, Cho SD. A case of tuberculous arthritis following the use of etanercept. Korean J Intern Med 2009; 24: 397-401.

4. Slifman NR, Gershon SK, Lee JH, Edwards ET, Braun MM. Listeria monocytogenes infection as a complication of treatment with tumor necrosis factor alpha-neutralizing agents. Arthritis Rheum 2003; 48: 319-24.

5. Kroesen S, Widmer AF, Tyndall A, Hasler P. Serious bacterial infections in patients with rheumatoid arthritis under anti-TNF therapy. Rheumatology 2003; 42: 617-21.

6. Bongartz T, Sutton AJ, Sweeting MJ, Buchan I, Matteson EL, Montori V. Anti-TNF antibody therapy in rheumatoid arthritis and the risk of serious infections and malignancies: systematic review and metaanalysis of rare harmful effects in randomized controlled trials. JAMA 2006; 295: 2275-85.

7. Leombruno JP, Einarson TR, Keystone EC. The safety of anti-tumour necrosis factor treatments in rheumatoid arthritis: meta and exposure- adjusted pooled analyses of serious adverse events. Ann Rheum Dis 2009; 68: 1136-45.

8. Galloway JB, Hyrich KL, Mercer LK, Dixon WG, Fu B, Ustianowski AP et al. Anti-TNF therapy is associated with an increased risk of serious infections in patients with rheumatoid arthritis especially in the first 6 months of treatment: updated results from the British Society for Rheumatology Biologics Register with special emphasis on risks in the elderly. Rheumatology (Oxford) 2011; 50: 124-31.

9. Atkins BL, Price EH, Tillyer L, Novelli V, Evans J. Salmonella osteomyelitis in sickle cell disease in children in the East End of London. J Infect 1997; 34: 133-8.

10. Behera B, Mathur P, Farooque K, Sharma V, Bhardwaj N, Thakur YK. Salmonella enterica enteritidis arthritis following trauma in a child with thalassemia major. Indian J Pediatr 2010; 77: 807-8.

11. Katsarolis I, Tsiodras S, Panagopoulos P, Giannitsioti E, Skarantavos G, Ioannidis T et al. Septic arthritis due to Salmonella enteritidis associated with infliximab use. Scand J Infect Dis 2005; 37: 304-5.

12. Gould ES, Gilet AG, Vigorita VJ. Granulomatous salmonella osteomyelitis associated with anti-tumor necrosis factor therapy in a non-sickle cell patient: a case report. Skeletal Radiol 2010; 39: 821-5.

13. Solovic I, Sester M, Gomez-Reino JJ, Rieder HL, Ehlers S, Milburn HJ et al. The risk of tuberculosis related to TNF antagonist therapies: a TBNET consensus statement. Eur Respir J 2010; 36: 1185-206. 